ISSN : $2302-1590$

ECONOMICA

E-ISSN: $2460-190 \mathrm{X}$

Jurnal Program Studi Pendidikan Ekonomi

STKIP PGRI Sumatera Barat Vol.9 No.1 (86 - 94)

\title{
THE EFFECT OF CTL MODELS AND ACTIVITY OF STUDENTS. TOWARDS LEARNING RESULTS
}

\author{
Oleh \\ Yuliana Gayatri $^{1)}$, Sri Wahyuni' ${ }^{2}$, Jimi Ronald ${ }^{3)}$ \\ ${ }^{1}$ Economy Study Program STKIP PGRI Sumatera Barat \\ Email: yulianagayatri1997@gmail.com \\ ${ }^{2)}$ Economy Study Program STKIP PGRI Sumatera Barat \\ Email: sriwahyuniajeng4@gmail.com \\ ${ }^{3)}$ Economy Study Program STKIP PGRI Sumatera Barat \\ Email: jimironaldstkippgrisumbar@gmail.com \\ Submitted: 2020.03.16 Reviewed: 2020.10.22 Accepted:2020.10.22 \\ https://doi.org/10.22202/economica.2020.v9.i1.3972
}

\begin{abstract}
This study aims to determine the effect of the CTL (Contextual Teaching And Learning) model (X1) and student activity (X2) on student learning outcomes (Y) class XI IPS SMAN 7 Mandau Duri 2018/2019 Academic Year. This type of research is Quasi-Experimental Design. This research was conducted at SMAN 7 Mandau Duri. This study was conducted in December 2019. The population in this study was students of class XI IPS at SMA N 7 Duri who were enrolled in the 2019/2020 school year, totaling 60 people. Sampling using Simple Random Sampling technique. The instrument used for the study was a closed questionnaire with the use of the Anova twoway test. The results showed that students who were taught using the Question Students Have method had significantly higher learning outcomes compared to students taught through the Conventional Method with Sig. $=0,000$, smaller than the value of $\alpha=0.05$ (Sig. $<A$ ). It is recommended for subject teachers to use the CTL (Contextual Teaching and Learning) learning method in the learning process at SMAN 7 Mandau Duri, especially in economics.
\end{abstract}

Jel Classification:

A2; A29; $A 30$

Keywords: Contextual Teaching and Learning method, Student Activity, Student Learning Results 


\section{INTRODUCTION}

Recent research, this study refers to research conducted by Ronald (2009: 2); (Kistian, 2018); (Urohmah, Halimah, \& Mulyadiprana, 2017); (Ikram, Rahman, \& Ningrum, 2019) on the Effect of Active Learning Models with Question Students Have Method and Learning Motivation Against Economic Learning Outcomes of Class Xi Ips Students in Senior High School 7 and Senior High School 8 Padang. The only difference is the use of different models and methods from the author. Considering the important role of economics in life, it is fitting for economic teaching to be presented in such a way as to attract attention, interest, and increase student activity in the learning process so that student learning outcomes are high. But the fact is the student's economic learning outcomes are not satisfactory. the purpose of this study is to find out whether the application of the CTL learning model can improve student activity and affect student learning outcomes better than not using the CTL learning model. Based on the observations of the authors of SMA $\mathrm{N} 7$ Mandau Duri, it turns out student learning outcomes are still low, as measured by student economic learning outcomes in the table below:

Table 1. Class XI IPS Class Assignment Value Data for 2018/2019

\begin{tabular}{cccccc}
\hline NO & Class & Average & KKM & Complete & Incomplete \\
\hline $\mathbf{1}$ & XI IPS 1 & 71 & 65 & 25 & $15 \%$ \\
$\mathbf{2}$ & XI IPS 2 & 50 & 65 & 28 & $20 \%$ \\
$\mathbf{3}$ & XI IPS 3 & 55 & 65 & 24 & $27 \%$ \\
\hline
\end{tabular}

Source: Economic Subject Teacher Class XI IPS N 7 Mandau Duri High School

Based on the table above, it can be seen that from 3 total classes of XI IPS totaling 90 students 2 classes have not yet reached the KKM (Minimum Completeness Criteria) set by the school, namely 65 classes XI IPS 2 with an average grade of 50 and grade XI IPS 3 with average learning outcomes of 55 which means it is still far below the KKM value. this shows that the value of economic learning outcomes obtained by students is still many who have not reached the KKM completeness level, which is equal to 65 . Many factors affect learning outcomes, one of which is thought to be caused by the activeness of students when teaching and learning are lacking, then the use of learning models is still monotonous or conventional, so that causes students to feel bored during the learning process and cannot focus on the material delivered by the teacher in class.

One effort to solve the problem is by applying an active learning model. According to Jimi Ronald (2009: 2) explains that "active" is diligent in trying or working. So active students will be marked by the interaction in asking and answering during the teaching and learning process that arises because of the curiosity of a material that has been explained by the teacher in class. here it is seen that the student has a serious desire to learn with the participation of questions and answers to obtain the information he wants to know.

The use of contextual learning will create classrooms in which students will be active participants, not just passive observers, and responsible for their learning. The application of contextual learning will greatly help teachers to connect subject matter with real-world situations and motivate students to form the relationship between knowledge and its application with their lives. Therefore the reason I chose to use the CTL (Contextual Teaching and Learning) learning model is that according to "(Bandono, 2008: 11)" CTL (Contextual Teaching and Learning) aims to help students to understand the 
meaning of teaching material by linking it to the context of their daily lives. day (personal, social, and cultural context), which can enhance students' dynamic and flexible knowledge/skills to actively construct their understanding.

It is expected that by selecting the CTL (Contextual Teaching and Learning) learning model compared to other models because by using the CTL (Contextual Teaching and Learning) learning model students can more easily understand the subject matter taught by teachers in the classroom because this model helps students relate it to everyday life that they feel and they live.

In addition to the CTL (Contextual Teaching and Learning) learning model, we need to apply the second factor that can affect student learning outcomes, namely learning activeness, According to Martinis Yamin, (2007: 80-81) explains that student activity in learning activities can be carried out when learning is done more studentcentered teacher acts as a guide so that learning experiences occur learning objectives of the student's minimum ability (basic competency) management of learning activities emphasize more on student creativity, enhance their minimum abilities, and create students who are creative and able to master concepts; and measuring continuously in various aspects of knowledge, attitudes, and skills.

Learning outcomes is several experiences gained by students that cover the cognitive, affective, and psychomotor domains. Learning is not only the mastery of the concept of subject theory but also the mastery of habits, perceptions, pleasures, interests-talents, social adjustments, kinds of skills, ideals, desires, and hopes. This is in line with the opinion of Rusman (2012: 123) which states that "Learning outcomes can be seen from the occurrence of changes in perception and behavior, including improvement in behavior".

According to Dimyati and Mudjiono (2006: 3), learning outcomes are the result of an act of learning and teaching. Jufri,
(2013: 58) states learning outcomes are abilities (performance) that can be observed in a person and are called capabilities. Five categories of learning outcomes according to Jufri are intellectual skills, cognitive strategies, verbal information, motor skills, and attitudes. Jufri (2013: 59) which classifies learning outcomes into three domains or domains, namely: (1) Cognitive, (2) Affective, (3) Psychomotor.

So from the experts' opinions above learning outcomes are experiences gained by students that cover the cognitive, affective, and psychomotor domains. Learning is not only mastery of the concept of subject theory, but also mastery of habits, perceptions, pleasures, interests-talents, social adjustments, kinds of skills, ideas, desires, and expectations that can be seen from the ability (performance) that can be observed in a person and called capability. Factors That Influence: Internal factors are factors that originate from within an individual and can influence individual learning outcomes. These internal factors include physiological factors, psychological factors, and fatigue factors, and External factors Besides the characteristics or exogenous factors, external factors can also affect student learning processes. In this case, Rusman (2012: 124) explains that external factors that influence learning can be grouped into three factors, namely family factors, school factors, and community factors.

So it can be concluded that two factors influence learning outcomes, namely internal factors originating from within students and external factors originating from outside students so that it can change student behavior for the better. So that it can improve student learning outcomes, especially in the cognitive domain of students.

According to "(Bandono, 2008: 11)" CTL (Contextual Teaching and Learning) is a holistic learning process and aims to help students to understand the meaning of teaching material by linking it to the context of their daily lives (personal, social and 
cultural context), so students have dynamic and flexible knowledge/skills to actively construct their understanding.

According to "Trianto, (2007: 101) Contextual learning or Contextual Teaching and Learning (CTL) is a conception that helps teachers link subject content with real-world situations and motivate students to make connections between knowledge and its application in their lives as family members, citizens country, and labor.

So the effect of the CTL (Contextual Teaching and Learning) Learning Model on student learning outcomes will create classrooms in which students will be active participants, not just passive observers, and responsible for their learning. The application of contextual learning will greatly help teachers to connect subject matter with real-world situations and motivate students to form relationships between knowledge and its application with their lives, which will be able to increase the value of student learning outcomes.

According to Ronald (2009: 2) explains that "active" is diligent in trying or working. So active students will be marked by the interaction in asking and answering during the teaching and learning process that arises because of the curiosity of a material that has been explained by the teacher in class. here it is seen that the student has a serious desire to learn with the participation of questions and answers to obtain the information he wants to know.

According to Martinis Yamin, (2007: 80-81) explains that the activeness of students in learning activities can be carried out when learning is carried out more centered on students, the teacher acts as a guide so that learning experiences achieve the objectives of learning activities achieved the minimum ability of students (basic competencies) management of activities learning places more emphasis on student creativity, increases their minimum abilities and reaches students who are creative and able to master concepts and take measurements continuously in various aspects of knowledge, attitudes, and skills.

So, from some of the opinions of the experts above the activeness of students is the interaction in asking and answering during the teaching and learning process that arises because of the curiosity of a material that has been explained by the teacher in class. Inactive learning the teacher positions himself more as a facilitator, whose task is to provide students with the ease of learning. Students are actively involved and play a role in the learning process, while the teacher only provides direction and guidance, and regulates the circulation and netting of the learning process.

The difference between this study and previous research conducted by Ronald (2009: 1); (Ridwanulloh, Jayadinata, \& Sudin, 2016); (Suarjana, Dibia, Luh, \& Sariani, 2018); (Hamdayani, 2013); (Latuconsina, Ika, \& Abrar, 2017) is in the variable of student learning activities. This study aims to determine the effect of the CTL (Contextual Teaching And Learning) model (X1) and student activity (X2) on student learning outcomes (Y) class XI IPS SMAN 7 Mandau Duri 2018/2019 Academic Year. This type of research is Quasi Experimental Design. This research was conducted at SMAN 7 Mandau Duri. This study was conducted in December 2019.

\section{METHODS}

Types of research Following the problem under study, this type of research is a type of Quasi Experiment research. According to Sugiyono (2010: 114) Quasi treatment experiments, outcome measures, and experimental units, but do not use random placement.

\section{Population and Sample}

The population is a group of objects to be studied. Following the title of the study, the population in this study were students of class XI IPS in SMA N 7 Duri who were enrolled in the 2019/2020 school year, which numbered 90 students. 
The sample in this study is class XI IPS 3 as a control class which has an average value lower than XI IPS 2 of SMAN 7 Mandau Duri, and the average value is higher than class XI IPS 1 of SMAN 7 Mandau Duri and class XI IPS 1 SMAN 7 Mandau Duri as an experimental class because the average value is the lowest among the three classes, the sample of this study amounted to 60 students, consisting of 30 students from the experimental class and 30 students from the control class. The analytical tool used in this study is to use a $2 \times 2$ factorial analysis. then to answer the research question using the 2-way ANOVA

\section{RESULTS AND DISCUSSION Research Result}

To analyze the research, the data is processed using descriptive data analysis techniques and inductive data analysis.

1. Descriptive Analysis Descriptive data is used to see or illustrate the data distribution tendency of each variable. In this section do the processing of data obtained in the field.

\section{Distribution of Student Learning} Activities.

In general, the activeness of the experimental class students who used the CTL (Contextual Teaching and Learning) learning method was in the high category with an average score of 4.42 and TCR (Respondent Achievement Level) of $88.34 \%$. While the activeness of control class students who use conventional methods is in the medium category with a mean score of 3.52 and TCR (Respondent Achievement Level) of $70.30 \%$. This means that in general, the activeness of students who use the CTL (Contextual Teaching and Learning) learning method is better than the activeness of students who use conventional learning methods.

\section{Distribution of Learning Outcomes}

At the beginning of the study, the authors determined the subject matter to be delivered in the sample class, the subject matter chosen by the author was the subject of monetary policy and fiscal policy in the two sample classes that applied two different learning methods. In the experimental class, the CTL (Contextual Teaching and Learning) learning method was applied while the control class applied the conventional learning method/lecture. It aims to see the extent of differences in student learning outcomes of the two sample classes. Learning is carried out during 2 meetings for each sample class.

From the economic learning outcomes of the experimental class and control class students in this study were obtained after conducting the learning process (Posttest). Posted is useful to see the ability of students in the two sample classes after being treated differently in the learning process. Posted value is presented in the form of a frequency distribution table by first determining the interval and number of groups.

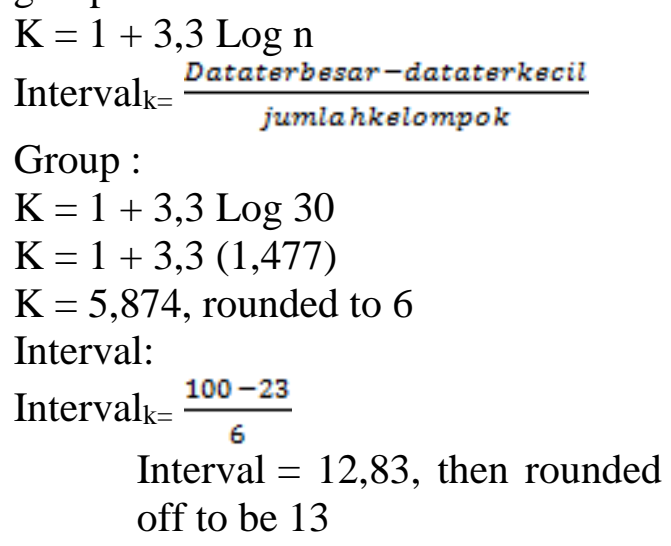

From the above data it can be seen, in the experimental class the lowest value obtained by students is 66 and the highest value obtained by students is 100 , then the range is 34 . While in the control class the lowest value obtained by students is 23 and the highest value obtained by students is 79 , then the range is 56 . So the value of the control class is more scattered than the value of the experimental class. 
In this experimental class, all students $100.0 \%$ of students have reached completeness, while in the control class that reached completeness is $3.3 \%$. Based on the established $\mathrm{KKM}$ that is 75 , the experimental class has fulfilled the KKM with $100.0 \%$ the number of students who complete. Whereas in the control class the number of students who completed was $3.3 \%$ and $96.7 \%$ had not yet met the KKM. This means that more experimental class students using the CTL (Contextual Teaching and Learning) learning method achieved mastery compared to the control class using conventional methods.

The average class learning outcomes in the experimental class is 82.87, while for the control class is 39.37. This means that the average value of students in the experimental class is higher than the control class and has a large average difference of 43.5. If seen from the overall average, the experimental class has passed the specified KKM limit, which is 75 .

The median value (Median) in the experimental class was 83.00, meaning that $50 \%$ of the 30 students of the experimental class scored below 83 , and the other $50 \%$ scored above 83 . While the median (Median) in the control class was 38 , meaning that $50 \%$ of the 30 control class students scored below 38, and the other 50\% scored above 38. This could mean that the scores obtained by the experimental class were higher than the control class.

For values that often appear (Mode) in the experimental class is 83 meaning that the experimental class students at the time of the posttest score a lot of 83. While in the control class the value that often appears (Mode) is 36 , meaning that the control class at the time of the posttest scores a lot 36 Meaning the value of the experimental class is better than the control class because in the experimental class many students get high grades.

The variance for the experimental class is 74,464 and the control class is 136,729 . The smaller the variance, the better it is because the average representative sample for the entire distribution of scores and more accurately describes the overall distribution. So the experimental class variance is better than the control class variance because the average experimental class is more accurate in describing the overall distribution.

Standard deviation is the average deviation of each score with the mean (mean) score. The standard deviation or deviation for the experimental class is 8.629 which means that the level of deviation of each average value at the posttest is 8.629. And in the control class that is 11.669 , it means that the level of deviation of each average value at the posttest is 11.669 . So, the data in the control class is better than the experimental class because the control class has more collected score distribution

\section{Grouping Learning Outcomes Based on Student Activity.}

1. High Student Activity Group.

From the results of the distribution of questionnaires about student activeness, researchers divided students from the experimental class and the control class into groups of students with high activity. The group of students with high activity in the experimental class had a total of 1252 with an average of 83.47. Whereas the control class had a total of 715 with an average of 47.67 . That is, the learning outcomes of groups of students who have high activeness using the CTL (Contextual Teaching and Learning) learning method are higher than the learning outcomes of students who have high activeness by using conventional learning methods.

\section{Low Student Activity Group.}


From the results of the distribution of questionnaires about student activity, researchers divided students from the experimental class and the control class into groups of students with low activity. The group of students with low activity in the experimental class had a total of 1234 with an average of 82.27. Whereas the control class had a total of 466 with an average of 31.07. That is, the learning outcomes of groups of students who have low activity using the CTL (Contextual Teaching and Learning) learning method is higher than the learning outcomes of students who have high activeness by using conventional learning methods.

\section{Hypothesis testing}

After conducting normality and homogeneity tests are met then the next step the author can proceed to the analysis of variance two paths. To find out whether the hypothesis proposed by the author is accepted or rejected. In processing this research data the writer uses SPSS 16.0. In testing hypotheses in a two-way analysis of variance, the criteria for rejecting or accepting or rejecting $\mathrm{Ha}$ are based on Significance (abbreviated as Sig.). If Sig. $<\alpha$ then Ho is rejected or Ha is accepted and vice versa if Sig. $>\alpha$ then Ho is accepted and $\mathrm{Ha}$ is rejected.

Based on Table 35, the hypothesis of this study is :

First Hypothesis, Students who are taught using the CTL (Contextual Teaching and Learning) method have significantly higher learning outcomes compared to students taught through Conventional Methods. The results of the two-way ANOVA analysis calculation shown in table 35 obtained the Sig level value. = 0,000 , this means that the Sig. smaller than the value of $\alpha=0.05$ ( $\mathrm{Sig} .<\alpha$ ) then Ho is rejected and $\mathrm{Ha}$ is accepted, so it can be concluded that the learning outcomes of students taught by using the CTL (Contextual Teaching and Learning) learning method are higher compared to classes taught using conventional learning methods in economic subjects class XI IPS 1 and XI IPS 3 SMA N 7 Mandau Duri. As the opinion of Sagala (2009: 142) "The use of various methods is one strategy to arouse students' motivation to learn so that the expected feedback from students occurs correctly". Which in turn will improve student learning outcomes.

Second Hypothesis, Students who have high student activity have significantly higher learning outcomes compared to students who have low student activity. The two-way ANOVA calculation results shown in table 35 obtained $\mathrm{Sig}$ levels. $=0,000$, this means Sig. smaller than the value of $\alpha=0.05$ ( $\mathrm{Sig} .<\alpha$ ) then Ho is rejected and $\mathrm{Ha}$ is accepted, so it can be concluded that students who have high student activeness have higher learning outcomes than student learning outcomes that have low student activity on economic subjects class XI IPS 1 and XI IPS 3 SMA N 7 Mandau Duri. As expressed by Sardiman (2009: 80) "motivation contains a desire that activates, moves, directs the attitudes and behavior of individual learning".

Third Hypothesis, There is an interaction of learning methods CTL (Contextual Teaching and Learning) with the activeness of student learning outcomes in class XI IPS 1 and XI IPS 3 SMA N 7 Mandau Duri. The results of the two-way ANOVA calculation for testing the third hypothesis can be seen in table 35 in the fifth row of the sixth column obtained by Sig. $=0.001$ this means the value of Sig. smaller than the value of $\alpha=0.05$ (Sig. $<\alpha$ ) then $\mathrm{Ho}$ is rejected and $\mathrm{Ha}$ is accepted, so there is an interaction of the CTL (Contextual Teaching and Learning) learning model and student activeness towards student learning outcomes in economic subjects in class XI IPS 1 and XI IPS 3 SMA N 7 Mandau Duri. Following the opinion of Zaini (2006: 17) states "student have question is an easy technique that can be used to determine the needs and expectations of students". This learning 
emphasizes students to be active and unite opinions and measures the extent to which students understand the lesson through written questions. The purpose of asking students to ask is to increase students' attention and curiosity about a topic, students are more active, students must learn to the maximum and develop their mindset.

\section{CONCLUSION}

Based on the results of the research and discussion of this study, it can be concluded that: "students who are taught with the CTL (Contextual Teaching and Learning) method have significantly higher learning outcomes compared to students taught through the Conventional Method with Sig. $=0,000$, smaller than the value of $\alpha=0.05$ (Sig. $<$ A) ".

\section{REFERENCES}

Bandono. (2008). "Developing a Contextual Teaching and LearningCTL Learning Model." Available at http://bandono.web.id. (accessed 07 September 2010).

Dimyati dan Mudjiono. 2006. Belajar dan Pembelajaran. Jakarta: PT Rineke Cipta

Dr. Rusman. (2012). learning models develop teacher professionalism. Jakarta: PT.Raja Grafindo Persada.

Hamdayani, F. (2013). Pengaruh Model Contextual Teaching And Learning (CTL) Terhadap Peningkatan Hasil Belajar IPA Siswa Kelas V SD Negeri 99 Pekanbaru, 1-9.

Ikram, T., Rahman, M. H., \& Ningrum, R. W. (2019). Pengaruh Model Pembelajaran Contextual Teaching And Learning ( CTL ) dan Aktivitas Siswa Terhadap Hasil Belajar Siswa Kelas X IPA 2 SMA Negeri 4 Halmahera Utara pada Konsep Gerak Lurus Abstrak, 4(1), 59-68.

Jimi Ronald. (2009). Improvement of Activities and Attitudes of
Independent Learning Through Model Questions Students Have on Economic Subjects in Class X SMA UNP Development. Economica.

Jufri (2013). Science Learning and Learning. Bandung: Copyright Reka Library.

Kistian, A. (2018). PENGARUH MODEL PEMBELAJARAN CONTEXTUAL TEACHING AND LEARNING ( CTL ) TERHADAP HASIL BELAJAR MATEMATIKA SISWA KELAS IV SD NEGERI, 5(2).

Latuconsina, N. K., Ika, A., \& Abrar, P. (2017). PENGARUH MODEL PEMBELAJARAN CONTEXTUAL TEACHING AND LEARNING ( CTL ) TERHADAP HASIL BELAJAR, 5(2), 70-75.

Martinis Yamin. (2007). Student Learning Tips. Jakarta: Gaung Persada Press and CLI.

Ridwanulloh, A., Jayadinata, A. K., \& Sudin, A. (2016). PENGARUH MODEL PEMBELAJARAN CONTEXTUAL TEACHING AND LEARNING ( CTL ) TERHADAP HASIL BELAJAR SISWA KELAS V PADA MATERI PESAWAT SEDERHANA, $1,731-740$.

Sagala, Syaiful. 2009. Manajemen strategi Dalam meningkatan Mutu Pendidikan. Bandung: Alfabeta

Sardiman. 2009. Interaksi dan Motivasi Belajar Mengajar. Jakarta: Rajawali Pers.

Sugiyono (n.d.). Educational Research Methods Quantitative, Qualitative, and R\&D Approaches. Bandung: Alfabeta.

Suarjana, I. M., Dibia, I. K., Luh, N., \& Sariani, A. (2018). Pengaruh Model Pembelajaran CTL Berorientasi Tri Kaya Parisudha terhadap Hasil Belajar Matematika, 2(3), 237-245. 
Trianto. (2007). CTL-Oriented Innovative Learning Models. Jakarta: Literature Achievement.

Urohmah, S., Halimah, M., \& Mulyadiprana, A. (2017). PEDADIDAKTIKA : JURNAL
ILMIAH PENDIDIKAN GURU SEKOLAH DASAR Pengaruh Model Kontekstual terhadap Hasil Belajar Siswa pada Materi Aktivitas Ekonomi, 4(1), 349-359. 